University of Wollongong

Research Online

Faculty of Engineering - Papers (Archive)

Faculty of Engineering and Information

Sciences

$1-1-2008$

\title{
Modelling of soft ground consolidation via combined surcharge and vacuum preloading
}

Buddhima Indraratna

University of Wollongong, indra@uow.edu.au

Cholachat Rujikiatkamjorn

University of Wollongong, cholacha@uow.edu.au

Ali Ghandeharioon

University of Wollongong, ag781@uow.edu.au

Follow this and additional works at: https://ro.uow.edu.au/engpapers

Part of the Engineering Commons

https://ro.uow.edu.au/engpapers/837

\section{Recommended Citation}

Indraratna, Buddhima; Rujikiatkamjorn, Cholachat; and Ghandeharioon, Ali: Modelling of soft ground consolidation via combined surcharge and vacuum preloading $2008,43-54$.

https://ro.uow.edu.au/engpapers/837

Research Online is the open access institutional repository for the University of Wollongong. For further information contact the UOW Library: research-pubs@uow.edu.au 


\title{
Modelling of soft ground consolidation via combined surcharge and vacuum preloading
}

\author{
B. Indraratna, C. Rujikiatkamjorn \& A. Ghandeharioon \\ School of Civil. Mining and Environnental Engineering, University of Wollongong, \\ Thollongong, Anstralia
}

\begin{abstract}
A system of vertical drains combined with vacuum and surcharge preloading is an effective approach for promoting radial flow to accelerate soft soil consolidation. Whenever a substantial load is required to meet the desired rate of settlement and if the cost of surcharge application is also significant, application of vacuum pressure with a reduced surcharge fill height can be used instead. The equivalent 2-D plane strain solution for multi-drain analysis is described including the effects of vacuum pressure and smear zone caused by mandrel driven vertical drains. A large-scale radial consolidometer is used to determine the extent of the smear zone, and the laboratory results are explained in detail. The equivalent (transformed) permeability coefficients are incorporated in finite element codes, employing the modified Cam-clay theory. The 2D and 3D numerical multi-drain analyses are conducted to predict the excess pore pressures, lateral and vertical displacements. The performance of two selected case histories are discussed and analysed, including the sites of Tianjin Port, China and Ska-Edeby embankment, Stockholm, Sweden. The numerical predictions are then compared with the available field data. This research demonstrates that, apart from realistic $3 \mathrm{D}$ numerical modelling, the equivalent plane strain solution can now be used as a predictive tool with an acceptable accuracy as a result of the significant process.
\end{abstract}

\section{INTRODUCTION}

Many coastal regions of Australia and Southeast Asia possess very soft clays (estuarine or marine), which have undesirable geotechnical properties such as low bearing capacity and high compressibility. In the absence of appropriate ground improvement (Indraratna and Redana 2000; Indraratna and Chu 2005), excessive settlement and lateral movement adversely affect the stability of buildings, ports and transport infrastructure built on soft formations. Limited space, tight construction schedules, environmental and safety issues, maintenance costs and the longevity of earth structures have continued to demand unfailing innovation in the design and construction of essential infrastructures on soft clays.

Moreover, the construction, design and stability problems are of economic significance in Australia, particularly along the East Coast in Northern Queensland (Cairns to Townsville) and the New South Wales coastal zone from Newcastle to the Queensland border. These areas are lined with saturated soft clays of 15-20 $\mathrm{m}$ depths. Improving the geotechnical properties of these soft soils will offer numerous benefits to regional communities in terms of infrastructure developments and maintenance.

The traditional preloading method of surcharge embankments used for improving the performance of soft clays is generally a low-cost solution. However, in very thick soft soil sites (more than $20 \mathrm{~m}$ deep soft soil deposits), there can be a significant delay in consolidation time due to the very low soil permeability and the lack of efficient drainage. When prefabricated vertical drains (PVDs) are installed in the ground, the drainage path length is shortened as a result of the radial flow, and the associated consolidation time is then reduced (Hansbo 1981; Holtz et al. 1991).

The installation of PVD, followed by the application of vacuum pressure (suction) as a preload at the soil surface, facilitates rapid dissipation of pore water pressure in the soil (Shang et al. 1998; Bergado et al. 2002; Bo et al. 2003). Suction pressures (negative) propagated along the drain length increase the radial hydraulic gradient towards the drains, hence, prevent the build up of excess pore water pressure in the soil, considerably reducing the risk of failure (Indraratna et al. 2004). 


\section{CHARACTERISTICS OF VACUUM PRELOADNG SYSTEM}

The vacuum preloading system was initially proposed by Kjellman (1952) via cardboard wick drains. It has been extensively used to accelerate the consolidation process of soft grounds and reclamation lands (Holtan 1965 and Yan and Chu 2003). For very soft clay formations, where high surcharge embankments cannot be raised without affecting stability, the vacuum application is the preferred alternative. PVD system has also been optimised to propagate vacuum pressure to the deep subsoil layers, thereby reducing the consolidation time (Indraratna et al. 2005, Chu et al. 2000). The effective stress increases due to vacuum pressure while the total stress remains constant.

Figure 1 compares the consolidation process in relation to the conventional method and the vacuumassisted preloading. The increase in effective stress in the soil mass in the latter is attributed to suction (negative pore pressures), in contrast to the conventional surcharge fill that increases the total stress (Qian et al. 1992; Indraratna et al. 2005). While the conventional surcharge preloading often induces excessive outward lateral displacements that may cause undrained shear failure, the vacuum induced suction would create inward lateral movements, and therefore, increases the lateral stability and also minimises swelling at the embankment toe (Rujikiatkamjorn et al. 2007).

\subsection{Types of vacuum preloading systems}

Currently, there are two types of vacuum preloading systems available commercially. Their effectiveness
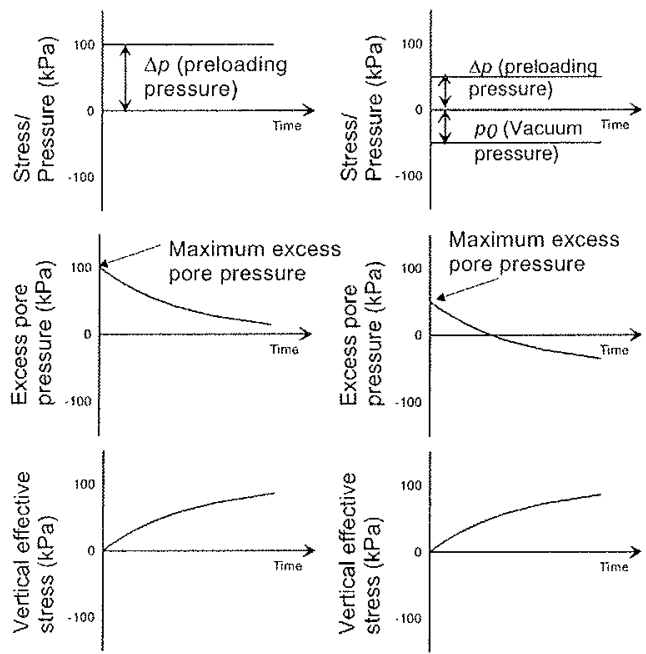

Figure 1. Consolidation process: (a) conventional loading (b) idealised vacuum preloading (Indraratna et al. 2005). is shown to vary with the type of soil treated and the nature of drains installed.

2.1.1 Vacuum preloading system with menbrane After installing the PVDs and a network of horizontal drains, a sand blanket is placed to cover the horizontal drains as a top drainage layer. The membrane is then placed over the sand blanket to ensure an airtight region above the PVDs (Fig. 2). The edge of the membrane is submerged in a bentonite slurry trench to prevent any peripheral air leaks. The vacuum pumps are then connected to the assembled discharge system extending from the trenches. PVDs with circular cross section are preferred by some contractors, however, they cause more smear than band shaped drains in general. An advantage of this system is that the suction generated by the pump propagates along the soil surface and down the PVDs within the airtight domain, accelerating the dissipation of pore water pressure both radially towards the PVDs and vertically towards the surface. Nevertheless, an obvious downfall of this method is that the efficiency of the entire system depends on the ability to prevent air leaks and to sustain sufficient suction over a significant period of time (Indraratna et al. 2004).

\subsubsection{Membraneless vacuum preloading system}

When an area has to be subdivided into a number of sections to facilitate the installation of the membrane, vacuum preloading can only be carried out sequentially, i.e. one section after another. This procedure may not be efficient, for instance, in land reclamation over a large area. One way of overcoming this problem is to connect the vacuum channel directly to each individual PVD using a tubing system, and then each PVD is connected directly to the drain collector (Fig. 3). Unlike the membrane system where any air leak can affect all the drains, in this system each drain acts independently. However, the requirement for extensive tubing for hundreds of drains surely affects

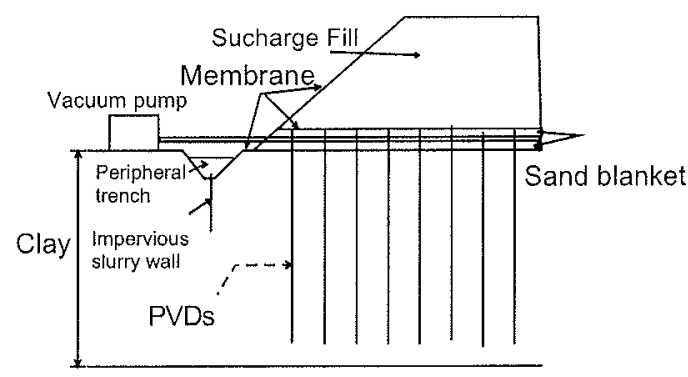

Figure 2. Schematic diagram of PVDs incorporating preloading system with membrane system (Indraratna et al 2005). 


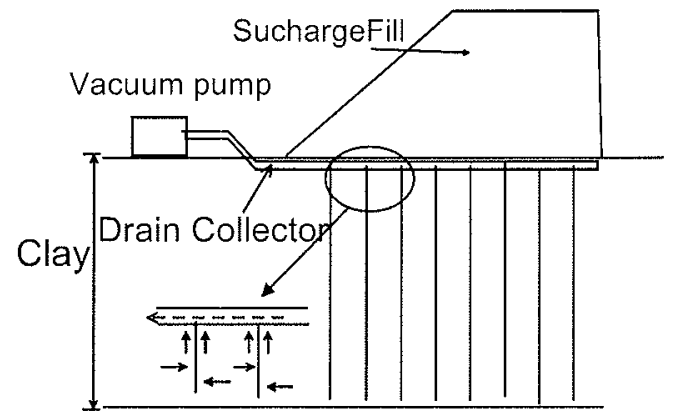

Figure 3. Schematic diagram of PVDs incorporating preloading system with membraneless system.

the installation time and cost (Seah 2006). Also, this system suffers the absence of a suction pressure distributed along the soil surface.

Observed in large-scale laboratory testings and field measurements, the vacuum pressure loss can be found along the drain length (Indraratna et al. 2005). The distribution pattern of vacuum pressure along the drain length depends on the sealing (i.c. no air leaks) and the type of soil around the drain. The laboratory findings in the large-scale consolidation test clearly confirms that the magnitude of suction gradually decreases along the drain length, thus, retarding the rate of consolidation settlement occurs. This suction pattern will be included in the theoretical development in the following section.

\section{EQUIVALENT PLANE STRAIN APPROACH FOR MULTI-DRAIN ANALYSIS}

To analyse a multi-drain system, most finite element analyses for radial consolidation are conducted based on the plane strain assumption, even though the flow around vertical drains is axisymmetric. Therefore, the equivalence between plane strain (2D) and axisymmetric (3D) analysis needs to be established. Hird et al. (1992); Indraratna and Redana 2000; Indraratna et al. (2005); Sathananthan and Indraratna (2006); Indraratna et al. (2008) proposed a plane strain conversion, which can be readily adapted to most field situations. Realistic field predictions require the insitu (axisymmetric) properties to be converted to equivalent $2 \mathrm{D}$ plane strain propertics, especially with regard to the permeability coefficients, vacuum pressure and drain geometry.

\subsection{Multi-drain analysis for a plane strain embankment}

Indraratna and Redana $(1997,2000)$ and Indraratna et al. (2005) transformed the vertical drain system from $3 \mathrm{D}$ to $2 \mathrm{D}$ plane strain condition by adjusting the coefficient of soil permeability (Fig. 4). The half width of the drain $b_{w}$ and half width of the smear zone $b_{s}$ remain the same as their axisymmetric radii $r_{i n}$ and $r_{s}$, respectively (i.e. $b_{w}=r_{w}$ and $b_{s}=r_{s}$ ).

Indraratna and Redana (2000) proposed a relationship between $k_{h y}$, and $k_{h p}$. The influence of the smear effect can be modelled as:

$$
\frac{k_{h p}^{\prime}}{k_{h p}}=\frac{\beta}{\frac{k_{h p}}{k_{h}}\left[\ln \left(\frac{n}{s}\right)+\left(\frac{k_{h}}{k_{h}^{\prime}}\right) \ln (s)-0.75\right]-\alpha}
$$

$\mu_{p}=\left[\alpha+(\beta) \frac{k_{h p}}{k_{h p}^{\prime}}\right]$

$\alpha=\frac{2}{3}-\frac{2 b_{s}}{B}\left(1-\frac{b_{s}}{B}+\frac{b_{s}^{2}}{3 B^{2}}\right)$

$\beta=\frac{1}{B^{2}}\left(b_{s}-b_{w}\right)^{2}+\frac{b_{s}}{3 B^{3}}\left(3 b_{w}^{2}-b_{s}^{2}\right)$

where, $\bar{u}_{0}=$ initial excess pore pressure, $\bar{u}=$ pore pressure at time $t$ (average values), $T_{h l y}=$ time factor in plane strain, $k_{h p}$ and $k_{h p}$ are the undisturbed horizontal coefficient of permeability and the corresponding equivalent coefficient of permeability in smear zone, respectively.

If the smear and well resistance effects are neglected in the above expressions, the simplified ratio of $2 \mathrm{D}$ to $3 \mathrm{D}$ axisymmetric permeability is read-

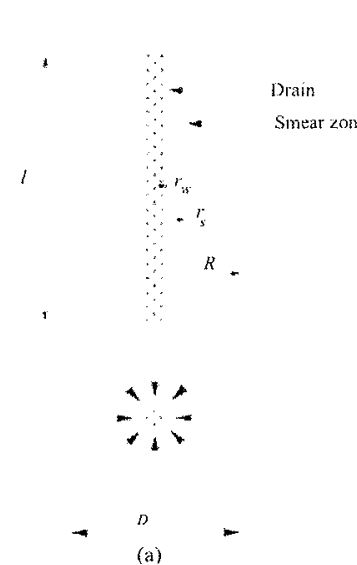

(a) Axisymmetric

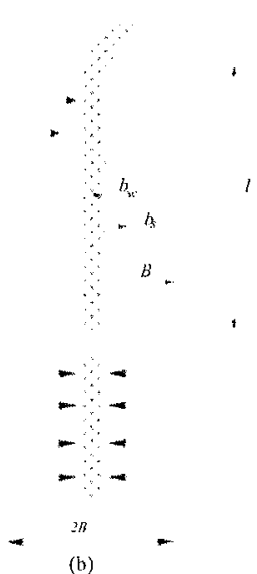

(b) Plane strain
Figure 4. Transformation of an axisymmetric unit cell into plane strain condition (after Indraratna and Redana 2000). 
ily obtained, as also proposed earlier by Hird et al. (1992), to be:

$$
\frac{k_{l p}}{k_{h}}=\frac{0.67}{[\ln (n)-0.75]}
$$

For vacuum preloading, the equivalent vacuum pressure under plane strain and axisymmetric conditions is the same.

\subsection{Multi-drain analysis for circular embankment}

Indraratna et al. (2008) proposed an equivalent plane strain model for radial consolidation via vertical drains beneath a circular loaded area, where the system con-

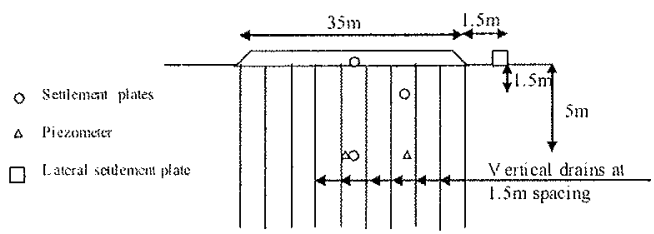

(a)

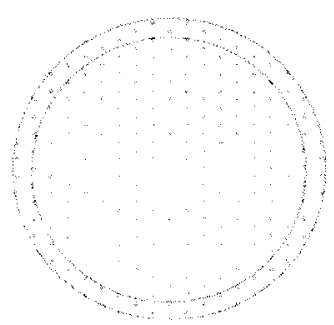

(b)

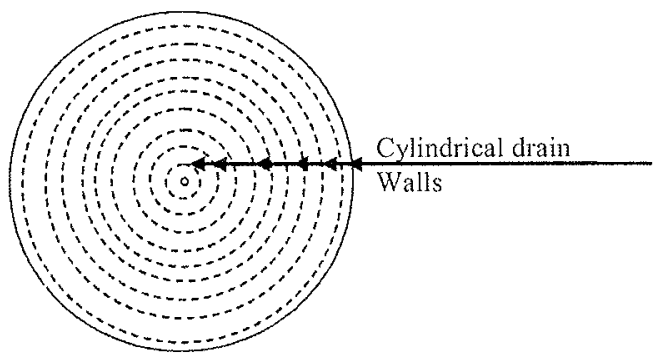

(c)

Figure 5. (a) Vertical cross section of an Embankment and the locations of instrumentation at Skă-Edeby, Sweden; (b) Plan view of the Embankment; (c) Conversion for multidrain system under circular loading adopted for analytical solutions (Hansbo 1960, Indratana et al, 2008). forms to an axisymmetric problem. In order to analyse a multi-drain system under a circular embankment, one must establish the equivalent soil parameters that give the same time-settlement response as in the field. In such a conversion, each drain element should behave as a part of concentric cylindrical drain wall with a larger perimeter as the radial distance from the centreline increases (Fig. 5)

The equivalent permeability for the multi-drain system under axisymmetric condition can then be expressed as:

$$
\frac{k_{h, \text { ring }}}{k_{h}}=\frac{\frac{2}{3} \alpha^{2}}{\left[\ln \left(\frac{n}{s}\right)+\frac{k_{h}}{k_{s}} \ln (s)-\frac{3}{4}\right]}
$$

where, $k_{h \text { rang }}=$ equivalent coefficient of horizontal permeability, $\alpha=0.887$ and 0.952 for drains installed in a square pattern and an equilateral triangular pattern, respectively.

\subsection{Multi-drain analysis for non-Darcian flow}

Sathananthan and Indraratna (2006a) determined the solution for the equivalent plane strain condition under non-Darcian flow. The converted permeability relationship is given by:

$$
\begin{aligned}
\kappa_{h p}= & 2 \kappa_{h}\left(\frac{n-1}{2 n^{2}} \frac{\beta_{p}}{\beta}\right)^{n} \\
\beta= & \frac{1}{3 n-1}-\frac{n-1}{n(3 n-1)(5 n-1)}-\frac{(n-1)^{2}}{2 n^{2}(5 n-1)(7 n-1)} \\
& +\frac{1}{2 n}\left[\left(\frac{\kappa_{h}}{\kappa_{s}}-1\right)\left(\frac{D}{d_{s}}\right)^{-(1-(1 / n))}-\frac{\kappa_{h}}{\kappa_{s}}\left(\frac{D}{d_{w}}\right)^{-(1-(1 / n))}\right]
\end{aligned}
$$

where, $D$ is the diameter of the drain influence zone, $d_{s}$ is the diameter of smear zone, $n=D / d_{w}$ where $d_{w}$ is the drain diameter, $u_{0}$ is the initial average excess pore water pressure.

Ignoring the smear effect in Eq. (7), the equivalent plane strain permeability in the undisturbed zone is now obtained as:

$$
\frac{\kappa_{h p}}{\kappa_{h}}=\frac{\lambda_{h p}}{\lambda}=2\left(\frac{f_{p}\left(n, \frac{b_{w}}{B}\right)}{2 f\left(n, \frac{r_{w}}{R}\right)}\right)^{n}
$$




$$
\begin{aligned}
f_{p}(n, y)= & {\left[\frac{1}{2 !}-\frac{1}{3 ! n}-\frac{(n-1)}{4 ! n^{2}}-\frac{(n-1)(2 n-1)}{5 ! n^{3}}-\frac{(n-1)(2 n-1)(3 n-1)}{6 ! n^{4}}-\cdots\right]-y-\frac{(n-1)}{2 ! n} y^{2}+\frac{(2 n-1)}{3 ! n^{2}} y^{3} } \\
& +\frac{(n-1)(3 n-1)}{4 ! n^{3}} y^{4}+\frac{(n-1)(2 n-1)(4 n-1)}{5 ! n^{4}} y^{5}+\frac{(n-1)(2 n-1)(3 n-1)(5 n-1)}{6 ! n^{5}} y^{6}+\cdots
\end{aligned}
$$

\section{DETERMINATION OF RADIAL CONSOLIDATION PARAMETERS}

\subsection{Equivalent drain diameter}

Flexible prefabricated vertical drain (PVD) systems have often replaced the original sand compaction piles and stone columns. The most common band-shaped drains have dimensions of $100 \mathrm{~mm} \times$ $4 \mathrm{~mm}$. For design purposes, the rectangular (width- $a$, thickness- $b$ ) section must be changed to an equivalent circle (diameter, $d_{w}$ ), because, circular drains are assumed in the conventional theory (Fig. 6).

The following typical equation is used to determine the equivalent drain diameter:

$d_{w}=2(a+b) / \pi($ Hansbo, 1979)

From the finite element studies, Rixner et al. (1986) proposed that:

$$
d_{w}=(a+b) / 2
$$

More recently, Long and Covo (1994) found that the equivalent diameter $d_{w}$ could be computed using an electrical analogue field plotter:

$$
d_{w}=0.5 a+0.7 b
$$

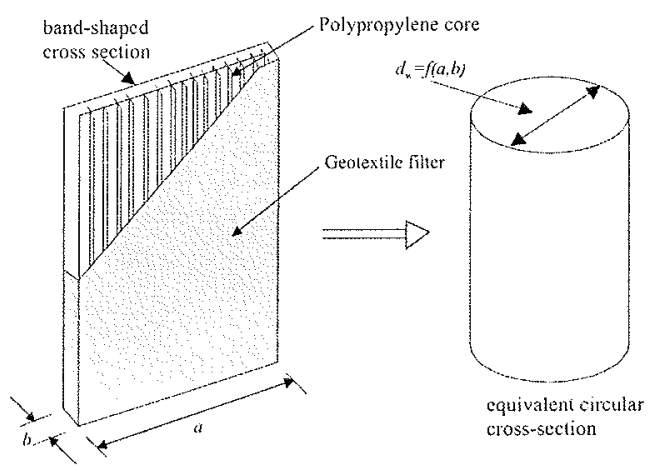

Figure 6. Conceptual illustration of band-shaped vertical drain and equivalent diameter of drain (Indraratna et al. 2005).

\subsection{Snear zone}

The smear zone is created once a PVD is installed using a steel mandrel. Soil hydraulic conductivity

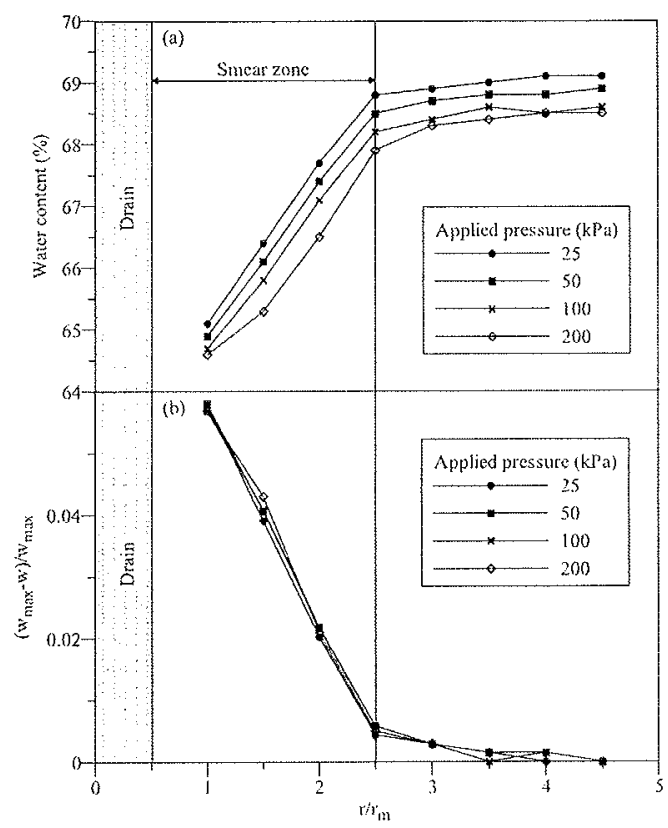

Figure 7. Determination of the smear zone based on water content variations (after Sathananthan and Indraratma 2006b).

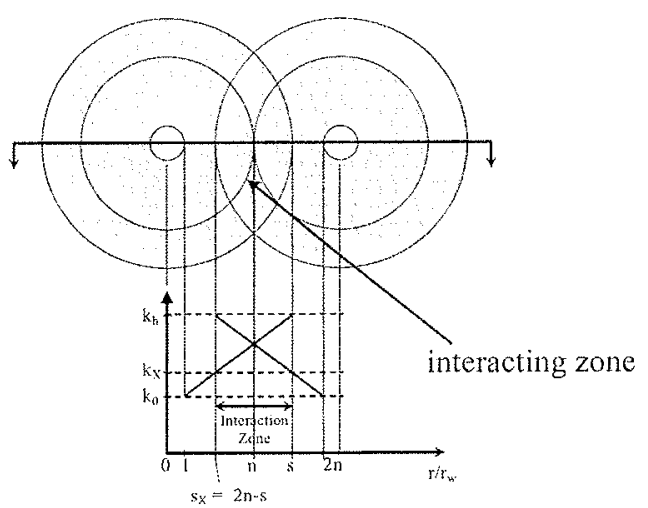

Figure 8. Overlapping smear zones (Walker and Indraratna 2007). 
around the PVDs can decrease significantly, which in turn retards the excess pore pressure dissipation rate and the consolidation process. The decrease in soil permeability can be determined by analysing the ratio of average soil permeability in the smear zone and the in-situ horizontal soil permeability $\left(k_{h} / k_{s}\right)$. This ratio and the size of smear zone $\left(d_{s}\right)$ depend on the soil sensitivity, mandrel shape, installation speed, and the soil macro fabric. These factors can be investigated using large-scale consolidation tests (Indraratna and Redana 1998; Sharma and Xiao 2000). The extent of the smear zone can be determined employing permeability and water content variations (Sathananthan and Indraratna 2006b).

Based on a number of large-scale tests carried out at University of Wollongong, the variation of the ratio of the horizontal to vertical coefficients of permeability $\left(k_{i} / k_{v}\right)$ at different consolidation pressures at various radii is shown in Figure 7. As expected, the water content and soil permeability decrease towards the drain. It is observed that the smear zone diameter is about $100 \mathrm{~mm}$ or 1.6 times the mandrel diameter and the ratio of $k_{h} / k_{\mathrm{s}}$ is approximately 2 . Walker and Indraratna (2007) showed that the smear effects can overlap creating more soil disturbance when the minimum influence radius is 0.6 times the smear zone radius (Fig. 8).

\section{APPLICATION TO CASE HISTORIES}

\subsection{Skå-Edeby Embankment, Stockholm, Sweden}

\subsubsection{Site description}

In order to obtain geotechnical information for construction of a new airport, four trial circular embankments were raised at about $25 \mathrm{~km}$ west of Stockholm, Sweden by the Swedish Geotechnical Institute and the Swedish Road Board in 1957 (Hansbo 1960). The study deals with a circular test embankment (Area II) with a base diameter of $35 \mathrm{~m}$, slope of $1.5 \mathrm{H}: 1 \mathrm{~V}$ and height of $1.5 \mathrm{~m}$. Sand drains of $0.18 \mathrm{~m}$ diameter were installed at a spacing of $1.5 \mathrm{~m}$. Gravel surcharge (unit weight of $17.9 \mathrm{kN} / \mathrm{m}^{3}$ ) was used after removing $0.25 \mathrm{~m}$ of the top soil. The water table was at $1.0 \mathrm{~m}$ below the ground surface. An array of instrumentations including settlement plates, piezometers and horizontal settlement gauges was installed to measure the vertical displacements, pore water pressures and lateral displacements, respectively. The locations were illustrated earlicr in Fig. 5a.

In general, these deposits can be considered as soft, normally consolidated clay. Site investigations showed that the subsoil profiles are fairly uniform, consisting of a weathered (over consolidated) crust with a total thickness of $1 \mathrm{~m}$, overlying an 8-10 $\mathrm{m}$ deep soft clay layer, which is followed by bedrock at a depth of 10 to $12 \mathrm{~m}$. The bulk unit weight generally increases from
$15 \mathrm{kN} / \mathrm{m}^{3}$ near the ground surface to $17 \mathrm{kN} / \mathrm{m}^{3}$ at the bottom of the soil profile. The conventional oedometer test was conducted to determine the compression and consolidation characteristies of the clay.

\subsubsection{Darcian vs. non-Dracian flow}

In Figure 9, the calculated degree of consolidation based on the Darcian axisymmetric, non-Darcian axisymmetric (Hansbo 1997) and non-Darcian plane strain solutions (Sathananthan and Indraratna 2006a) are plotted along with the available field data at the embankment centerline. The predicted values based on the non-Darcian flow seem to agree better with the field data in comparison with the Darcian (conventional) analysis. However, in the opinion of the authors, this difference is generally negligible,

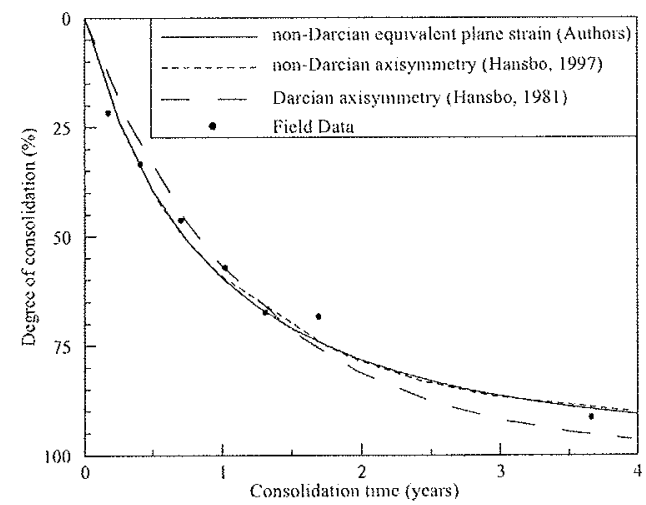

Figure 9. Estimation of the degree of consolidation at the embankment centreline with time, Ska-Edeby field study (after Hansbo 1997; Sathananthan \& Indraratna 2006a)

Table 1. Soil properties used in the analysis (adopted from Hansbo, 1960)

\begin{tabular}{|c|c|c|c|c|}
\hline & Layer 1 & Layer 2 & Layer 3 & Layer 4 \\
\hline Depth (m) & $0.0 \cdots 1.0$ & 1.03 .0 & 3.06 .0 & $6.0 \cdots 11$ \\
\hline \multicolumn{5}{|l|}{ Unit Weight } \\
\hline$\left(\mathrm{kN} / \mathrm{m}^{3}\right)$ & 14.2 & 14.5 & 15.6 & 16 \\
\hline \multicolumn{5}{|l|}{ Pre-consolidation } \\
\hline pressure $(\mathrm{kPa})$ & 27 & 24 & 35 & 48 \\
\hline$k_{v}$ and $k_{s}(\mathrm{~m} /$ year $)$ & 0.0075 & 0.0064 & 0.005 & 0.008 \\
\hline $\begin{array}{l}k_{k}(\text { m/year }) \\
\quad(\mathrm{m} / \text { year })\end{array}$ & 0.03 & 0.026 & 0.02 & 0.032 \\
\hline (Eq. 6) & 0.0029 & 0.0025 & 0.0019 & 0.0031 \\
\hline$\lambda$ & & 0.93 & 1.55 & 1.54 \\
\hline K & & 0.093 & 0.155 & 0.154 \\
\hline$c^{\prime}(\mathrm{kPa})$ & 30 & & & \\
\hline$\phi^{\prime}$ & 30 & & & \\
\hline $\mathrm{E}(\mathrm{MPa})$ & 2.7 & & & \\
\hline
\end{tabular}


and for all practical purposes the conventional Darcy conditions are sufficient.

5.1.3 Multi-drain analysis for circular embankment Figure 10 presents the finite element mesh consisted of 28160 rectangular CAX8RP elements (8-node biquadratic displacement, bilinear pore pressure). The relevant soil parametcrs of the four subsoil layers are tabulated in Table 1 based on laboratory test results provided by Hansbo (1960). For the topmost over-consolidated crust layer, the Mohr-Coulomb model was employed. It was assumed that the diameter of the smear zone $(d)$ was $0.36 \mathrm{~m}$ and that both the permeability of the smear zone $\left(k_{s}\right)$ and the vertical soil permeability $\left(k_{v}\right)$ were 0.25 times the horizontal undisturbed soil permeability $\left(k_{h}\right)$. For the multi-drain analysis, the permeability of soil for each layer under the circular embankment loading was calculated based on the Equation (6), while the Equation (5) was adopted for the plane strain condition. An embankment surcharge loading of $27 \mathrm{kPa}$ was simulated by applying incremental linear vertical loads to the upper boundary for 30 days, followed by a rest period.

In this section, the field data are compared with numerical predictions based on the multi-drain analysis under both axisymmetric and plane strain conditions (Indraratna et al. 2008). The comparison between the predicted and recorded field settlements at the centreline of the embankment at the ground surface is shown in Fig. 11. The predicted settlements from the axisymmetric conditions employing Equation (6) agree well with the measured results and also with those predicted by Hansbo (1997). However, the plane strain analysis underestimates the field results.

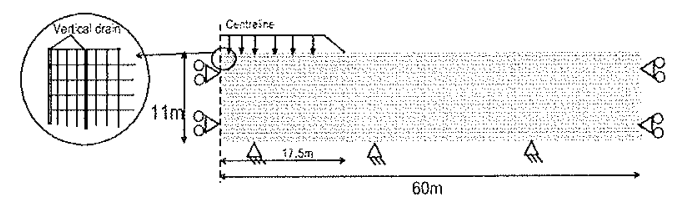

Figure 10. Tinite element mesh (after Indraratna et al. 2008).

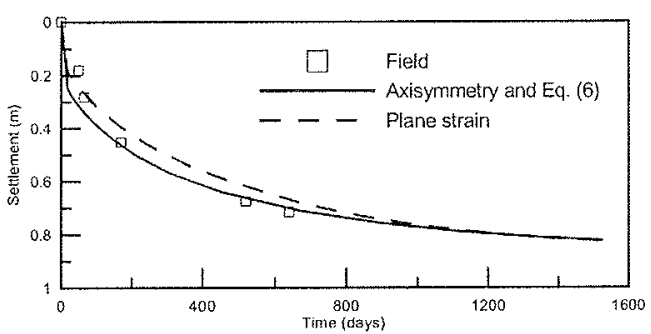

Figure 11. Surface settlements at the centreline (after Indraratna et al. 2008).
The excess pore pressure predictions in both cases at $5 \mathrm{~m}$ depth and at a lateral distance of $0.75 \mathrm{~m}$ away from the embankment centreline also agree with the field measurements (Fig. 12).

The profiles of the lateral displacements at the ground surface are shown in Fig. 13. It can be seen that the predictions made on the basis of axisymmetric condition are less than those for the plane strain condition. In general, for a circular foundation stabilised by vertical drains, the axisymmetric analysis with an appropriate conversion procedure is critical to accurately predict settlement, excess pore pressure and lateral displacement.

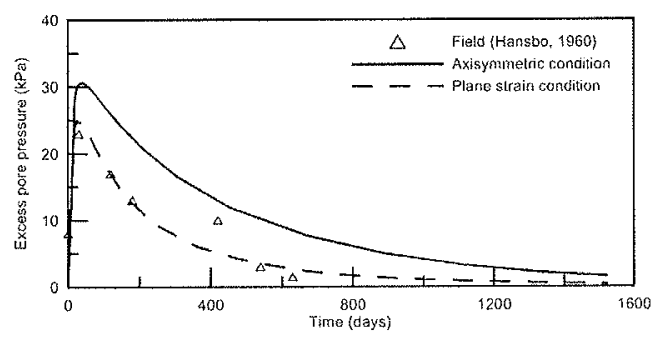

Figure 12. Excess pore pressure (after Indraratua et al. 2008).

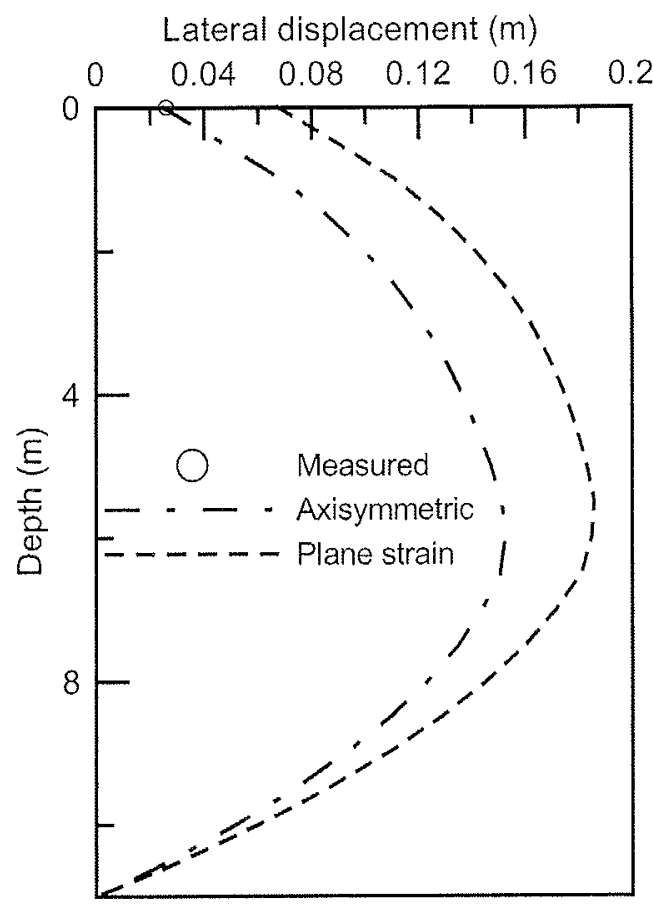

Figure 13. Profiles of the lateral displacement at $1.5 \mathrm{~m}$ from the embankment edge after 300 days. 


\subsection{A storage site at Tianjin Port, China}

\subsubsection{Site description}

Tianjin Port is approximately $100 \mathrm{~km}$ from Beijing, China ( $\mathrm{Chu}$ and Yan 2005). The top 3-4 m of the soil deposit was reclaimed using clay slurry from the seabed. The soft muddy clay was about $5 \mathrm{~m}$ underneath the reclaimed soil, followed by a soft muddy clay layer at a depth of $8.5-16 \mathrm{~m}$. The groundwater level is located at the ground surface.

The critical state soil properties were obtained using the triaxial and standard oedometer tests. The soil parameters related to the four subsoil layers for $2 \mathrm{D}$ and $3 \mathrm{D}$ analyses are summarized in Table 2 . The soil permeability used in plane strain analysis was determined from the Equations (1) to (5) (Table 3). At this site, a vacuum pressure (suction) of $80 \mathrm{kPa}$ was applied. It was observed that the reduction in

Table 2. Parameters for soil compressibility (Rujikiatkamjorn et al. 2008).

\begin{tabular}{llllll}
\hline Depth (m) & $\lambda$ & $\kappa$ & $v^{\prime}$ & $e_{0}$ & $\gamma \mathrm{kN} / \mathrm{m}^{3}$ \\
\hline $0.0-3.5$ & 0.12 & 0.03 & 0.3 & 1.1 & 18.3 \\
$3.5-8.5$ & 0.14 & 0.03 & 0.25 & 1.0 & 18.8 \\
$8.5-16.0$ & 0.20 & 0.04 & 0.3 & 1.35 & 17.5 \\
$16.0-20.0$ & 0.10 & 0.02 & 0.27 & 0.9 & 18.5 \\
\hline
\end{tabular}

Table 3. 2D and 3D Parameters for soil permeability (Rujikiatkamjorn et al. 2008).

\begin{tabular}{lccccc}
\hline $\begin{array}{l}\text { Depth } \\
(\mathrm{m})\end{array}$ & $\begin{array}{l}k_{v} \\
10^{-10}\end{array}$ & $\begin{array}{l}k_{h, a x} \\
10^{-10} \\
\mathrm{~m} / \mathrm{s}\end{array}$ & $\begin{array}{l}k_{s, a x} \\
10^{-10} \\
\mathrm{~m} / \mathrm{s}\end{array}$ & $\begin{array}{l}k_{h, p s} \\
10^{-10} \\
\mathrm{~m} / \mathrm{s}\end{array}$ & $\begin{array}{l}k_{s, p s} \\
10^{-10} \\
\mathrm{~m} / \mathrm{s}\end{array}$ \\
\hline $0.0-3.5$ & 6.67 & 20 & 6.67 & 5.91 & 1.46 \\
$3.5-8.5$ & 13.3 & 40 & 13.3 & 11.8 & 2.92 \\
$8.5-16.0$ & 6.67 & 20 & 6.67 & 5.91 & 1.46 \\
$16.0-20.0$ & 1.67 & 5 & 1.67 & 1.48 & 0.365 \\
\hline
\end{tabular}

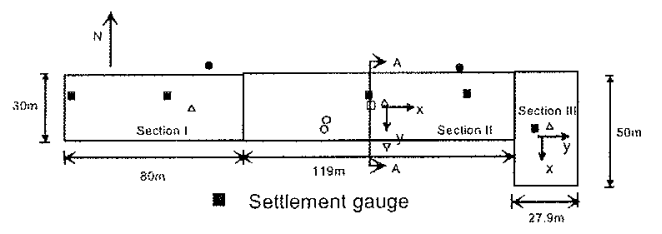

D Pore water transducer

- Field vane

- Inclinometer

$\nabla$ Piezometer

$\triangle$ Mutti-level gauge

Figure 14. Field instrumentation and embankment plan view at Tianjin Port (Rujikiatkamjorn et al, 2007). pore pressure was constant along the entire depth of PVDs ( $80 \mathrm{kPa})$. Therefore, the vacuum pressure was assumed to be unchanged along the drain elements and the soil surface.

After applying the vacuum pressure for about 1 month, the embankment surcharge was raised to provide the additional pressures of 50 and $60 \mathrm{kPa}$ for Sections II and III, respectively. Figure 14 illustrates the locations of instrumentation for Section II, including the settlement gauges, pore water pressure transducers, multi-level gauges, inclinometers and piezometers. PVDs ( $100 \mathrm{~mm} \times 3 \mathrm{~mm}$ ) of $20 \mathrm{~m}$ long were installed at $1 \mathrm{~m}$ spacing (a square pattern).

A finite element program (ABAQUS v.6.5.1) coupled with Biot consolidation theory was used to simulate the 3D and 2D multi-drain analysis (Hibbitt, et al. 2005). As the geometric aspect ratio of Section II was four $(119 \mathrm{~m} / 30 \mathrm{~m})$ the plane strain condition could be assumed, and therefore only half of a row of vertical drains with their influence zones was simulated (Fig. 15) under plane strain condition. The 3D finite element mesh consists of 90000 C3D8RP solid elements (8-node tri-linear displacement and pore pressure) (Fig. 15).

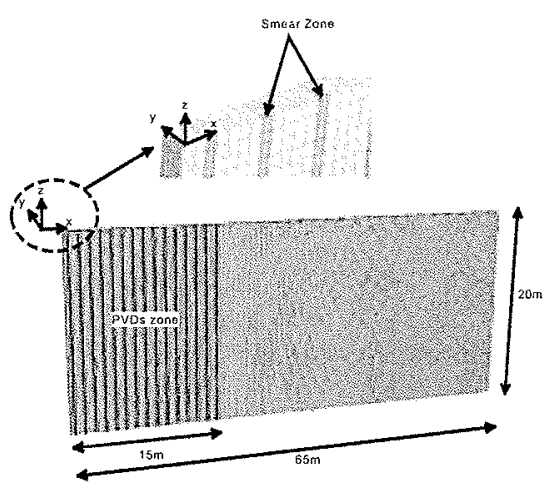

Figure 15. 2D Finite element mesh for Section II (Rujikiatkanjorn et al. 2008).

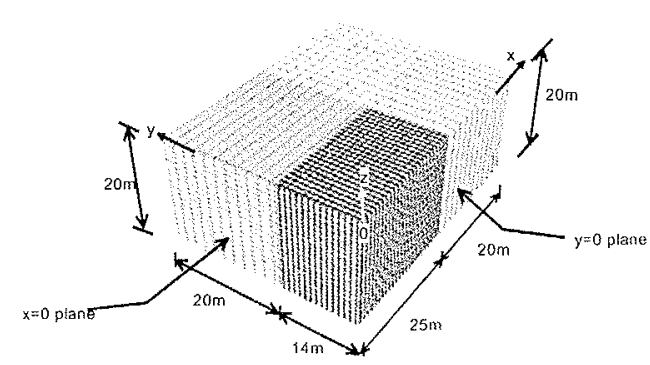

Figure 16. 3D Finite element mesh for Section III (Rujikiatkamjorn et al. 2007). 
Since Section III had a very low aspect ratio (less than 2), a quarter of the embankment area in Section III $\left(15 \times 25 \mathrm{~m}^{2}\right)$ was employed in the model. The 3D finite element mesh consists of 101160 C3D8RP solid elements (Fig. 16) with a total of 350 individual band drains. The cross section of the smear zone, in relation to the shape of mandrel, was considered as rectangular in shape $\left(150 \times 200 \mathrm{~mm}^{2}\right)$. The ratio of the horizontal permeability in the undisturbed zone to the horizontal permeability in the smear zone $\left(k_{h} / k_{s}\right)$ was in the range of $1.5-2.0$.

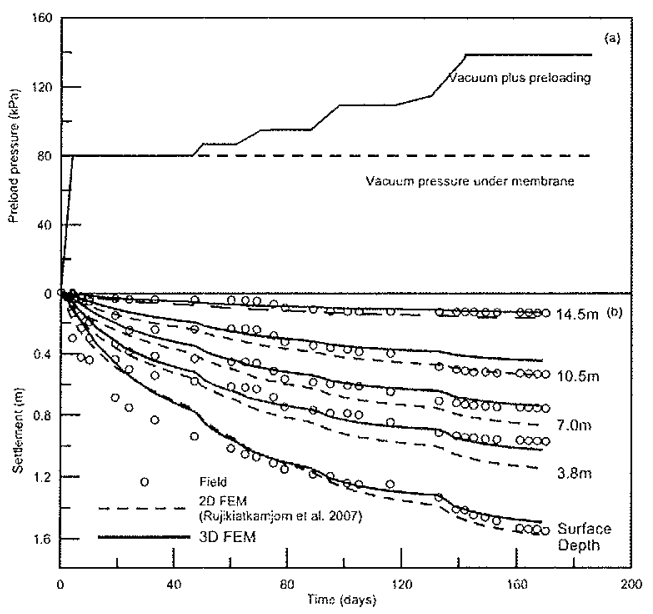

Figure 17. Section II (a) Loading history and (b) Consolidation settlements (Rujikiatkamjorn ef al. 2008).

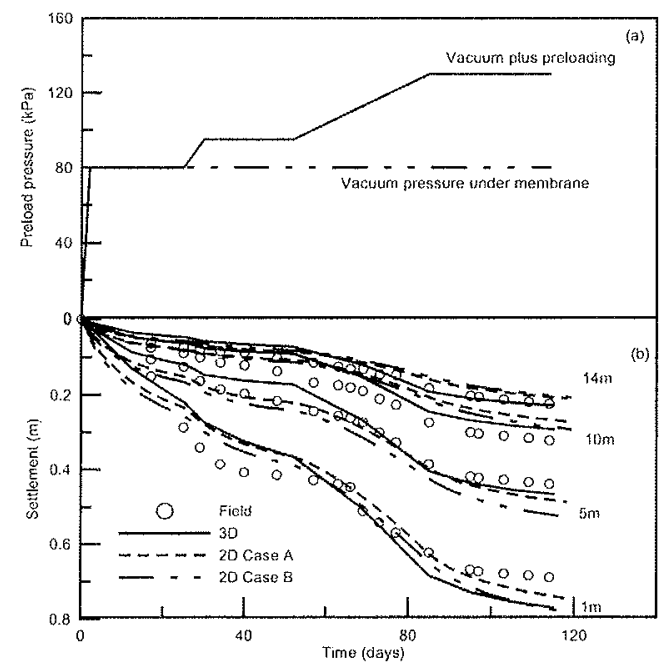

Figure 18. Section III (a) Loading history and (b) Consolidation settlements (Rujikiatkamjorn et al. 2008).

\subsection{2 $2 D$ vs. $3 D$ multi-drain analysis}

Figures 17 and 18 present a comparison between the predicted and measured settlements at the centreline of the embankment along with the loading history for Sections II and III, respectively. The settlement predictions from $3 \mathrm{D}$ and $2 \mathrm{D}$ analyses are almost the same. Pore pressure reductions obtained from 2D are more than those from 3D FEM analysis during the initial 2 months (Fig, 19). The pore pressures become constant $(-80 \mathrm{kPa})$ after about 4 months.

The comparison between the measured and predicted lateral movements at the toe of the embankment (Section II) after 5.5 months is presented in Fig. 20. The negative lateral displacement denotes an inward soil movement towards the centreline of the embankment. The predictions from 2D and 3D are in acceptable agreement with the field data

The results obtained from the 3D and 2D approaches based on the permeability conversion proposed by Indraratna et al. (2005) are slightly

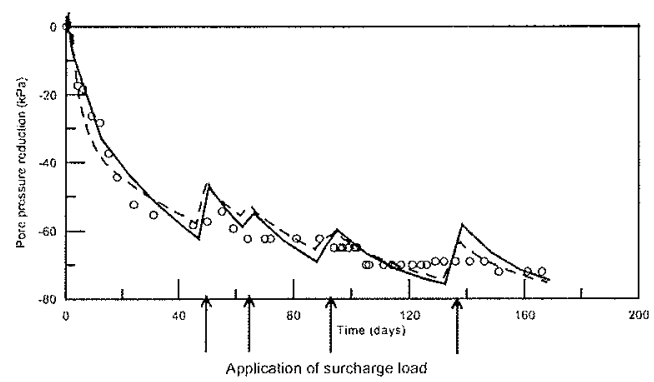

Figure 19. Pore pressure variation at $0.25 \mathrm{~m}$ away from the embankment centreline (Section II): $11.0 \mathrm{~m}$ depth (arrows indicate times when surcharge loads were applied) (Rujikin atkamjorn et al. 2008).

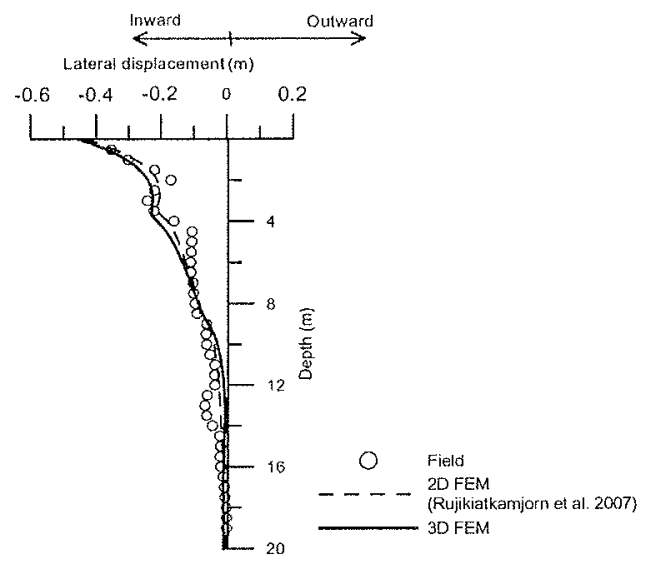

Figure 20. Lateral displacements at embankment toe (Section II) at 168th day (Rujikiatkamjorn et al. 2008). 
different to each other. The entire range of average degree of consolidation curve obtained from the equivalent $2 \mathrm{D}$ condition is almost identical to that estimated in 3D condition, hence the differences in pore pressures and lateral displacement predictions were insignificant. In this case history, it appears that the equivalent plane strain analysis can be applied with confidence, rather than a cumbersome threedimensional analysis.

\section{CONCLUSIONS}

A system of vertical drains combined with vacuum preloading is an effective method to accelerate soil consolidation by promoting radial flow. Conversion procedures for multi-drain analyses considering Darcy and Non-Darcy flow were proposed. For large construction sites, at which many PVDs are installed, the plane strain analysis is more than sufficient given the computational efficiency. Recently developed conversion method from axisymmetric to plane strain condition gives acceptable agreement with the measured data.

The 3D and 2D finite element analyses were executed to simulate the consolidation of soil under combined vacuum and surcharge (fill) loading. In the 3D analysis, the embankment geometry with individual PVDs and assumed rectangular smear zones were considered. In the equivalent plane strain analysis, the conversion method was used to establish the equivalent coefficient of the permeability in both the smear and undisturbed zones. The modified Cam-clay theory was adopted as the appropriate soil constitutive model. The use of a constant vacuum pressure at the soil surface and along the drain interface is appropriate to determine of the settlements, excess pore water pressures at different depths and for predicting the lateral movements. These numerical predictions obtained from both 2D and 3D analyses compared well with the field measurements.

It is found that the results obtained from equivalent 2D and actual 3D analyses in terms of settlements, excess pore pressures and lateral displacements were very similar. Therefore, the equivalent plane strain approach is sufficient to conduct multi-drain analysis in large projects, for which the application of this 2-D plane strain model is efficient both in a computational point of view and accuracy of the predictions.

\section{ACKNOWLEDGEMENTS}

The authors wish to thank the Queensland Department of Main Roads (Australia) for its continuing support. A number of other current and past doctoral students, namely, Dr. I. Redana, Dr. C. Bamunawita,
Dr. R. Walker and Dr. I. Sathananthan have also contributed to the contents of this keynote paper More elaborate details of the contents discussed in this paper can be found in previous publications of the first author and his research students in ASCE and Canadian Geotechnical Journals, since mid 1990's.

\section{REFERENCES}

Bergado, D.T., Balasubramaniam, A.S., Fannin, R.J, and Holtz, R.D. (2002). Prefabricated Vertical Drain (PVD) in Soft Bangkok Clay: A Case of NBIA Project, Canadian Geotechnical Journal, 39: 304-315.

Bo, M.W., Chu, J., Low, B.K. and Choa, V. (2003). Soil Improvement; Prefabricated Vertical Drain Techniques, Thomson Learning, Singapore.

Chu, J, and Yan, S.W. (2005). Estimation of degree of consolictation for vacuum preloading projects. International Journal of Geomechanics, ASCE, 5(2): 158--165.

Chu, J., Yan, S.W. and Yang, H. (2000). Soil improvement by the vacuum preloading method for an oil storage station. Geotechnique, 50(6): 625632 .

Hansbo, S. (1960). Consolidation of clay with special reference to influence of vertical sand drains. Swedish Geotechnical Institute, Proc., No. 18,160 p.

Hansbo, S. (1979). Consolidation of clay by band-shaped prefabricated drains. Ground Eng., 12(5): 16-25.

Hansbo, S. (1997). Aspects of vertical drain design--Darcian or non-Darcian flow. Géotechnique 47(5): 983-992.

Hansbo, S. (1981). Consolidation of fine-grained soils by prefabricated drains. Proc, 10th Int. Conf. on Soil Mechanics and Foundation Engineering, Stockholm, Sweden, 3: 677-682.

Hibbitt, Karlsson and Sorensen (2006). ABAQUS/Standard User's Manual, Published by HKS Inc.

Hird, C.C., Pyrahm, I.C. and Russel, D. (1992). Finite element modeling of vertical drains beneath embankments on soft ground. Geotechnique, 42(3): $499 \ldots 511$.

Holtan, G.W. (1965). Vacuum stabilization of subsoil beneath runway extension at Philadelphia International Airport. In Proc. of 6th ICSMFE, 2

Holtz, R.D., Jamiolkowski, M., Lancellotta, R. and Pedroni, S. (1991). Prefabricated vertical drains: design and performance, CIRIA ground engineering report; ground improvement. Butterworth-Hememam Ltd, UK, $131 \mathrm{p}$.

Indraratna, B. and Chu, J. (2005). Ground lmprovement - Case Histories Book (Volume 3), Elsevier, London 1115 p.

Indraratna, B. and Redana, I.W. (1998). Laboratory determination of smear zone due to vertical drain installation. Journal of Geotechnical Engineering, ASCE, 125(1): $96-99$.

Indraratna, B. and Redana, I,W. (2000). Numerical modeling of vertical drains with smear and well resistance installed in soft clay. Canadian Gcotechnical Journal, 37: 1--14.

Indraratna, B., Aljorany, A. and Rujikiatkanjorn C. (2008). Analytical and Numerical Modelling of Consolidation by Sand Drains beneath a Circular Embankment. International Journal of Geomechanies (In press).

Indraratna, B., Bamunawita, C, and Khabbaz, H. (2004), Numerical modeling of vacuum preloading and field applications. Canadian Geotechnical Journal, 41: 1098 -1110. 
Indraratna, B., Rujikiatkamjorn C., Balasubramaniam, A.S. and Wijeyakulasuriya, V.(2005). Predictions and observations of soft clay foundations stabilized with geosynthetic drains and vacuum surcharge. Ground ImprovementCase Histories Book (Volume 3), Edited by Indraratna, B. and Chu, J., Elsevier, London, 199-230.

Kjellman, W. (1948). Accelerating consolidation of fine grain soils by means of cardboard wicks. Proc. 2nd ICSMFE, 2, 302 305 .

Long, R.P. and Covo, A. (1994). Equivalent diameter of vertical drains with an oblong cross section. Joumal of Geotechnical Engineering Division, ASCE, 120(9): $1625 \cdots 1630$.

Qian, J.H., Zhao, W.B., Cheung, Y.K. and Lee, P.K.K. (1992). The theory and practice of vacuum preloading. Computers and Geotechnics, 13: 103-118.

Rixncr, J.J., Kraemer, S.R. and Smith, A.D. (1986). Prefabricated Vertical Drains, Vol. I, II and III: Summary of Research Report-Final Report. Federal Highway Admin., Report No. FHWA-RD-86/169, Washington D.C., 433 p.

Rujikiatkamjorn, C., Indraratna, B. and Chu, J. (2007). Numerical modelling of soft soil stabilized by vertical drains, combining surcharge and vacuum preloading for a storage yard. Canadian Geotechnical Journal, 44:326-342.

Rujikiatkamjorn, C., Indrarama, B, and Chu, J. (2008). 2D and $3 \mathrm{D}$ Numerical Modeling of Combined Surcharge and
Vacuum Preloading with Vertical Drains. International Journal of Geomechanics, ASCE, 8(2), 144-156.

Sathananthan, I and Indraratma, B. (2006a). Plane Strain Lateral Consolidation with Non-Darcian Flow. Canadian Gcotechnical Journal, 43:119 133 .

Sathananthan, 1. and Indraratna, B. (2006b). Laboratory Evaluation of Smear Zone and Correlation between Permeability and Moisture Content. Journal of Geotechnical and Geocnvironmental Engineering, ASCE, 132(7): 942-945.

Seah, T.H. (2006). Design and construction of ground improvement works at Suvarnabhumi Airport. Geot. Eng, J, of Southeast Asian Geotechnical. Society, 37, $171 \cdots 188$.

Sharma, J.S. and Xiao, D. (2000). Characterization of a smear zone around vertical drains by large-scale laboratory tests. Canadian Geotechnical Journal, 37(6): 1265-1271.

Shang, J.Q., Tang, M. and Miao, Z. (1998). Vacuum preloading consolidation of reclaimed land: a case study. Canadian Geotechnical Journal, 35: 740-749

Walker, R. and Indraratna, B. (2007). Vertical drain consolidation with overlapping smear zones. Geotechnique, Institution of Civil Engineers, UK, Vol. 57 No. 5 . pp. $463-467$.

Yan, S.W. and Clu, J. (2003). Soil improvenent for a road using a vacuum preloading method. Ground Improvement, $7(4): 165-172$. 